\title{
FORMULASI PRODUK SUSU FERMENTASI KERING DENGAN PENAMBAHAN BAKTERI PROBIOTIK Lactobacillus casei DAN Bifidobacterium longum
}

\author{
(Formulation of Dried Fermented Milk Product by Addition of Probiotic Bacteria of Lactobacillus casei \\ and Bifidobacterium longum)
}

\author{
Dida Hanifa Rahman ${ }^{1 *}$, Ikeu Tanziha ${ }^{1}$, dan Sri Usmiati² \\ ${ }^{1}$ Departemen Gizi Masyarakat, Fakultas Ekologi Manusia (FEMA), Institut Pertanian Bogor, \\ Jl. Raya Darmaga, 16680 \\ ${ }^{2}$ Balai Besar Penelitian dan Pengembangan Pasca Panen, Cimanggu, Bogor
}

\begin{abstract}
Fermented milk is a healthy product that has many benefits especially for human digestive tract. Manufacturing of probiotic fermented milk products as a functional food with a viable long shelf life needs to be developed. The purpose of this study was to formulate a dried fermented milk product using probiotic bacterias. The experimental design study was a complete random design with 4 treatments using different lactic acid bacteria (LAB): $A 1$ (Streptococcus lactis: 0.5\%); A2 (Streptococcus lactis: $0.25 \%$ and Lactobacillus casei: $0.25 \%$ ); $A 3$ (Streptococcus lactis: $0.25 \%$, Lactobacillus bulgaricus: $0.125 \%$, Streptococcus thermophiles: $0.125 \%$ ); and $A 4$ (Streptococcus lactis: $0.25 \%$ and Bifidobacterium longum: $0.25 \%$ ). The highest level of hardness was $A 2$ product and the highest level of tenderness is $A 1$ product. Results of proximate analysis showed that dried fermented milk products had high levels of the protein, calcium, and phosphorus. Microbiological test results showed that the amount of lactic acid bacteria (BAL) in dried fermented milk products were eligible based on CODEX: 243 (2003). Statictical analysis using ANOVA in the hedonic quality test showed that the treatments were significantly different $(p<0.05)$ on texture, hardness and taste attributes, but not significantly different on color and aroma attributes. The results of hedonic test showed that the treatment were not significant ( $p>0.05)$ on the attributes of color, aroma, hardness, and flavor except texture.
\end{abstract}

Key words: dried fermented milk, functional food, probiotic, lactic acid bacteria (LAB)

\begin{abstract}
ABSTRAK
Susu fermentasi merupakan produk kesehatan yang mempunyai banyak manfaat terutama untuk saluran pencernaan manusia. Pembuatan produk susu fermentasi probiotik sebagai makanan fungsional yang mempunyai kelangsungan hidup dan daya simpan yang lama perlu dikembangan. Tujuan penelitian ini adalah untuk memformulasikan susu fermentasi kering menggunakan bakteri probiotik. Desain penelitian yang digunakan adalah rancangan acak lengkap dengan 4 perlakuan menggunakan 4 bakteri asam laktat (BAL), (Streptococcus lactis, 0.5\%), A2 (Streptococcus lactis; 0.25\% dan Lactobacillus casei; 0.25\%), A3 (Streptococcus lactis; 0.25\%, Lactobacillus bulgaricus: $0.125 \%$, dan Streptococcus thermophilus; $0.125 \%$ ). Tingkat kekerasan tertinggi yaitu pada produk A2 dan tingkat kelembutan produk tertinggi pada produk A1. Analisis proksimat menunjukkan bahwa susu fermentasi kering memiliki kadar protein, kalsium, dan fosfor yang tinggi. Uji mikrobiologi menunjukkan bahwa jumlah bakteri asam laktat (BAL) pada susu fermentasi kering memenuhi syarat berdasarkan CODEX: 243 (2003). Analisis statistik menggunakan ANOVA pada uji mutu hedonik menunjukkan bahwa perlakuan berpengaruh $(\mathrm{p}<0.05)$ pada tekstur, kekerasan, dan rasa, tetapi tidak pada warna dan aroma. Hasil uji statistik pada uji hedonik menunjukkan bahwa perlakuan berpengaruh nyata $(p<0.05)$ pada tekstur kecuali warna, aroma, kekerasan, dan rasa.
\end{abstract}

Kata kunci: susu fermentasi kering, pangan fungsional, probiotik, bakteri asam laktat (BAL)

"Korespondensi: Departemen Gizi Masyarakat, Fakultas Ekologi Manusia (FEMA), IPB, Jl. Raya Darmaga, 16680, Email: didagizi@gmail.com 


\section{PENDAHULUAN}

Kesadaran masyarakat terhadap pentingnya kesehatan telah meningkat sehingga masyarakat mulai memilih bahan makanan yang benar-benar bermanfaat bagi kesehatan dirinya. Hal tersebut mendorong berkembangnya riset mengenai makanan dan minuman yang mempunyai efek menyehatkan termasuk pangan fungsional yang berasal dari ternak. Pangan fungsional adalah makanan dengan manfaat kesehatan yang melebihi nilai gizi dari pangan tersebut, dimana pangan tersebut telah dimodifikasi atau dikombinasikan dalam rangka meningkatkan manfaat kesehatan dan bersifat farmakologis (Galland 2005). Bioproduk atau makanan yang mengandung probiotik tergolong ke dalam pangan fungsional karena selain mengenyangkan, juga berpotensi dalam meningkatkan fungsi fisiologis usus dengan cara memodifikasi mikroflora usus. Makanan yang mengandung probiotik selain mempunyai fungsi gizi yang baik, terbukti pula dapat memberi manfaat kesehatan dan terapeutik serta bisa dijadikan antibiotik untuk menekan pertumbuhan bakteri patogen.

Mikroflora usus merupakan bagian dari sistem organ manusia yang berperan dalam mengoptimalkan kesehatan tubuh. Kondisi kesehatan yang baik dipengaruhi oleh "mikroba baik" yang berguna bagi kesehatan yang kebanyakan dikelompokkan sebagai bakteri asam laktat (BAL). Bakteri tersebut harus mampu melewati beberapa rintangan seperti keasaman lambung yang tinggi, keberadaan antibiotik dan sekresi garam empedu dalam usus halus. Selain itu BAL juga mampu menghasilkan senyawa antimikroba untuk menekan pertumbuhan bakteri patogen (Winarno et al. 2003).

Pembuatan produk fermentasi merupakan teknologi yang sudah dikenal oleh manusia sejak hampir 4000 tahun yang lalu. Semenjak itu, penggunaan bahan mentah tertentu, pembuatan spesifik, dan teknologi penyimpanan terus berkembang dan menjadi tradisi di setiap daerah lokal (Caplice \& Fitzgeralda 1999). Pembuatan produk susu fermentasi kering dengan penambahan probiotik merupakan teknologi yang masih baru di Indonesia. Oleh karena itu diperlukan riset untuk mengembangkan pangan fungsional berbahan dasar susu sapi sebagai produk kesehatan masa kini.

\section{METODE}

\section{Desain, Waktu dan Tempat}

Penelitian dilaksanakan pada bulan April hingga September 2011, bertempat di Balai Besar Penelitian dan Pengembangan Pascapanen Pertanian $\mathrm{Ci}$ manggu, Bogor. Penelitian ini menggunakan desain eksperimental dengan Rancangan Acak Lengkap.

\section{Bahan dan Alat}

Bahan yang digunakan terdiri dari bahan utama dan bahan pendukung. Bahan utama adalah susu sapi yang didapatkan dari peternak sapi di kawasan Kunak, Ciampea, Bogor dan kultur BAL (Streptococcus lactis, Lactobacillus bulgaricus, Streptococcus thermophilus, Lactobacillus casei dan Bifidobacterium longum). Bahan pendukung yang digunakan adalah gula pasir. Bahan kimia yang digunakan adalah de Mann Rogosa Sharpe Broth (MRSB), de Mann Rogosa Sharpe Agar (MRSA), media M17 agar, media Plate Count Agar (PCA), larutan $\mathrm{NaCl} 0.85 \%$, akuades, $\mathrm{NaOH} 0.1 \mathrm{~N}$, indikator $\mathrm{PP}$, larutan ribosa $1 \%$, bile salts, larutan laktosa $1 \%$, $\mathrm{LiCl}$, sodium propionat, prussian blue.

Peralatan yang digunakan dalam penelitian dibagi dalam beberapa tahap yaitu alat untuk membuat produk fermentasi kering, alat untuk analisis dan alat untuk uji organoleptik. Peralatan untuk membuat produk fermentasi kering antara lain panci alumunium besar, pengaduk kayu, termometer, gelas ukur, panci alumunium semianaerob, kain saring, mortar, sendok, sodet, cetakan alumunium, pipet mikro, pipet volumetrik, loyang dan oven. Alat-alat untuk analisis fisik produk yaitu texture analyzer (merk TexturePro CT V1.2 Build 9, Brookfield Engineering Labs, Inc), dan penetrometer (merk Precision Petroleum Analyzer, Company San Antonio Texas). Peralatan untuk analisis mikrobiologi terdiri dari cawan petri dan colony counter. Adapun peralatan analisis kimia meliputi erlenmeyer, kompor, penangas air, tanur, oven (merk Imperial V Laboratory Oven, USA), pH meter, cawan porselen, alat destilasi, alat titrasi, alat-alat gelas, dan peralatan lainnya.

\section{Tahapan Penelitian}

Penelitian ini terdiri dari penelitian pendahuluan dan penelitian utama. Penelitan pendahuluan bertujuan untuk mendapatkan kurva pertumbuhan bakteri dan menentukan waktu inokulasi kultur dengan susu sapi sebelum proses fermentasi. Adapun penelitian utama bertujuan untuk mendapatkan produk dengan perlakuan yang telah ditetapkan.

Penelitian utama adalah pembuatan produk fermentasi kering berbahan baku susu sapi dengan penambahan probiotik (Gambar 1). Metode ini didasarkan pada penelitian yang dilakukan oleh Jandal (1996) dan telah dimodifikasi oleh Hidayatulloh (2011). Produk susu fermentasi kering dibuat dengan menggunakan 4 perlakuan yang berbeda pada penggunaan kultur BAL. Produk A1 adalah sebagai kontrol menggunakan kultur bakteri Streptococcus lactis $0.5 \%$, produk A2 menggunakan kultur bakteri Streptococcus lactis : Lactobacillus casei (0.25\% : $0.25 \%)$, produk A3 menggunakan kultur bakteri Streptococcus lactis : Lactobacillus bulgaricus: Streptococcus thermophilus $(0.25 \%: 0.125 \%$ : 


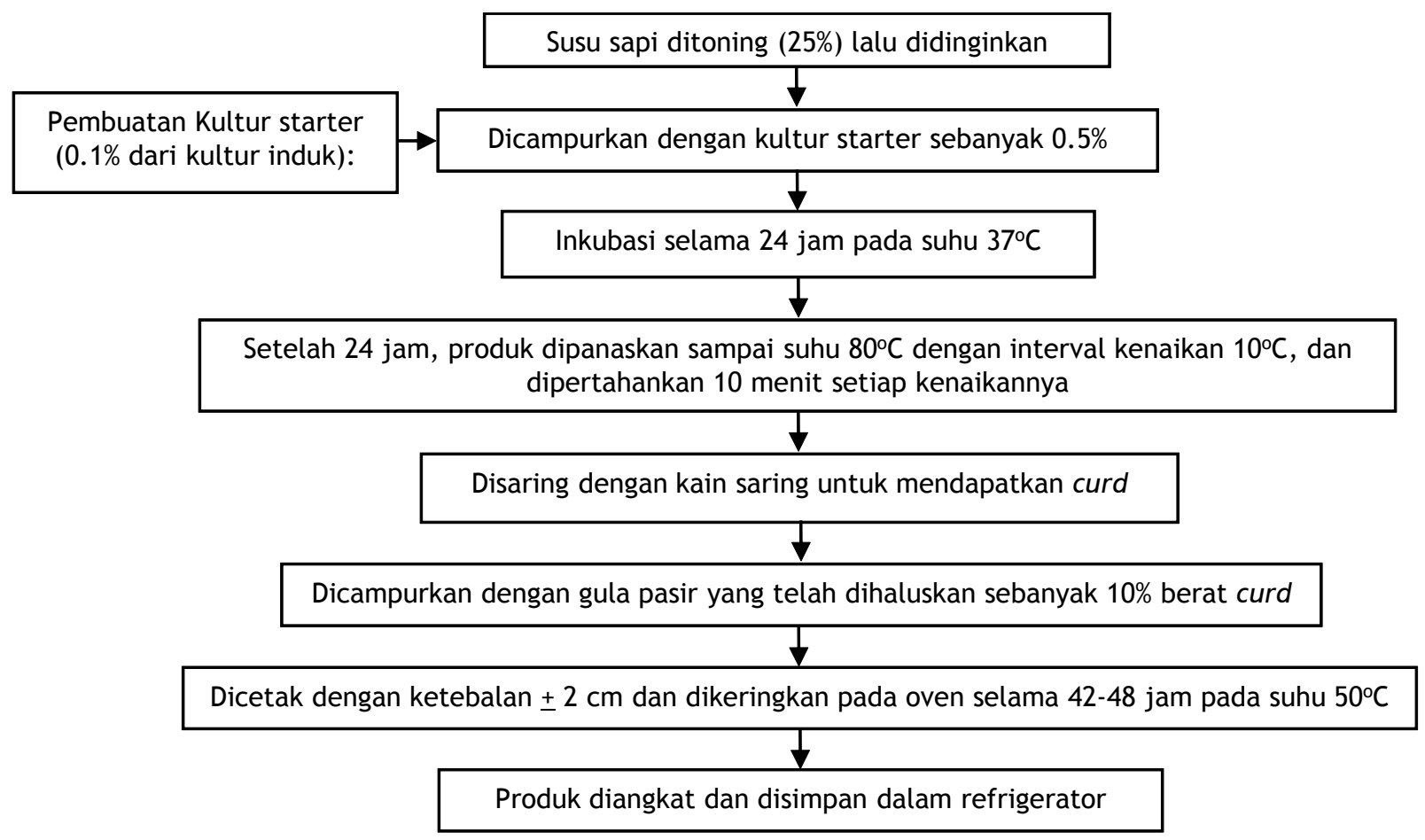

Gambar 1. Diagram Alir Tahapan Pembuatan Produk berdasarkan Hidayatulloh (2011)

0.125), dan produk A4 menggunakan kultur bakteri Streptococcus lactis: Bifidobacterium longum $(0.25 \%: 0.25 \%)$. Pembuatan produk dilakukan sebanyak 3 kali ulangan untuk mendapatkan data yang valid.

Produk fermentasi kering berbahan baku susu dengan penambahan probiotik ini dianalisis atas sifat fisik, kimia, dan mikrobiologi. Sifat fisik yang dianalisis yaitu tingkat kelembutan dan kekerasannya. Sifat kimia yang dianalisis meliputi kadar air (metode oven SNI 01-2891-1992), kadar protein (metode soxhlet SNI 01-2891-1992), kadar karbohidrat (Winarno 1986), kadar abu (metode tanur SNI 012891-1992), kadar fosfor (Apriyantono et al. 1989), kadar kalsium (Apriyantono et al. 1989) dan kadar lemak (metode Weibull SNI 01-2891-1992).

Analisis mikrobiologi yang dilakukan mencakup uji Total Plate Count (TPC), uji selektif yang mencakup selektif $S$. lactis, enumerasi dan selektif differensial dengan mengacu pada metode yang digunakan oleh Tabasco et al. (2007) yang disajikan pada Tabel 1. Uji organoleptik dilakukan untuk menilai mutu hedonik dan kesukaan panelis. Jumlah panelis yang digunakan adalah 30 orang.

Pengolahan dan Analisis Data

Data hasil analisis fisikokimia dan uji organoleptik pada skala hedonik dan mutu hedonik diolah dengan Microsoft Excell 2007 lalu kemudian dianalisis dengan sidik ragam One Way Anova lalu diuji lanjut dengan uji lanjut Duncan dengan menggunakan software SPSS 16.0. Sedangkan data hasil analisis mikrobiologi dibandingkan dengan standar mutu produk susu fermentasi. Perbandingan dilakukan hanya kepada uji mikrobiologi dikarenakan belum ada SNI untuk produk susu fermentasi kering di Indonesia.

\section{HASIL DAN PEMBAHASAN}

Penelitian terdahulu oleh Suprihanto (2009) menghasilkan kurva pertumbuhan BAL Lactobacillus casei, Lactobacillus bulgaricus dan Bifidobacterium

Tabel 1. Bakteri BAL beserta Media Selektif, Enumerasi, dan Differensial yang Digunakan

\begin{tabular}{ccc}
\hline Bakteri & Media & Lama, suhu, dan kondisi \\
\hline S. lactis & M17 (selektif) & 48 jam suhu $37^{\circ} \mathrm{C}$ aerob \\
L. casei & $M R S A+1 \% \mathrm{~b} / \mathrm{v}$ ribosa (Enumerasi) & 72 jam suhu $27^{\circ} \mathrm{C}$ anaerob \\
L. bulgaricus & $\mathrm{MRSA}+0.15 \mathrm{~b} / \mathrm{v}$ bile salt (Differensial) & 72 jam suhu $27^{\circ} \mathrm{C}$ aerob \\
S. thermophilus & $\mathrm{MRSA} \mathrm{pH} 5.2$ (Enumerasi) & 72 jam inkubasi $43^{\circ} \mathrm{C}$ anaerob \\
B. longum & $\mathrm{M} 17+1 \% \mathrm{~b} / \mathrm{v}$ laktosa (enumerasi) & 24 jam inkubasi $45^{\circ} \mathrm{C}$ anaerob \\
& $\mathrm{MRSA}+\mathrm{LiCl} 2 \mathrm{gr} / \mathrm{L}+3 \mathrm{gr} / \mathrm{L}$ sodium propionat (Enumerasi) & 48 jam suhu $37^{\circ} \mathrm{C}$ anaerob \\
$\mathrm{RCA}+$ prussian blue pH 5 (Differensial) & 72 jam suhu $37^{\circ} \mathrm{C}$ aerob \\
\hline
\end{tabular}


longum. Kurva pertumbuhan ini bertujuan untuk mengetahui fase awal BAL mengalami pertumbuhan eksponensial. Fase adaptasi BAL pada awal pertumbuhan sangat diperlukan untuk menentukan usia kultur kerja setiap bakteri agar bakteri dalam kondisi yang sama, yaitu kondisi bakteri akan melakukan pertumbuhan secara eksponensial (titik akhir adaptasi). Hal ini juga dimaksudkan agar pertumbuhan BAL mencapai jumlah maksimal saat kultur starter dicampurkan dengan susu sebelum proses fermentasi (Suprihanto 2009).

Kurva pertumbuhan BAL menunjukkan bahwa fase adaptasi pada kultur BAL S. lactis terjadi pada jam ke-4, L. casei jam ke-4, L. Bulgaricus jam ke-4, S. thermophilus jam ke-2, dan B. longum pada jam ke-3.

\section{Tingkat kekerasan}

Kekerasan merupakan salah satu penilaian karakter fisik produk dan biasanya diukur dengan cara menekannya menggunakan tangan atau digigit menggunakan gigi. Berdasarkan uji sidik ragam yang dilakukan, perlakuan tidak berpengaruh nyata $(P>0.05)$ terhadap kekerasan produk susu fermentasi kering. Rata-rata nilai tingkat kekerasan produk susu fermentasi kering berturut-turut yaitu A1 (905.06 g), A4 (910.83 g), A3 (1145.44 g), dan A2 (1193.44 g). Perlakuan A2 menghasilkan produk susu fermentasi kering yang paling keras (1193.44 g).

\section{Tingkat Kelembutan}

Kelembutan suatu produk dapat dirasakan dengan mengunyahnya di dalam mulut. Hasil uji sidik ragam menunjukkan bahwa perlakuan tidak berpengaruh nyata $(P>0.05)$ terhadap kelembutan produk susu fermentasi kering. Perlakuan A1 mempunyai tingkat kelembutan yang paling lembut yaitu sebesar $18 \mathrm{~kg} / \mathrm{s}$. Kelembutan produk susu fermentasi kering dari yang paling lembut secara berturut- turut adalah A1 $(18.00 \mathrm{~kg} / \mathrm{s})$, A2 $(16.50 \mathrm{~kg} / \mathrm{s})$, A4 $(13.39 \mathrm{~kg} / \mathrm{s})$, dan A3 $(13.28 \mathrm{~kg} / \mathrm{s})$.

\section{Analisis Kandungan Gizi Susu Fermentasi Kering}

Analisis kandungan gizi susu fermentasi kering disajikan pada Gambar 2 dan Gambar 3.

\section{Kadar lemak}

Berdasarkan uji sidik ragam, tampak bahwa perlakuan tidak berpengaruh nyata $(P>0.05)$ terhadap kadar lemak produk susu fermentasi kering. Kadar lemak pada produk susu fermentasi kering terendah dihasilkan dari perlakuan A4 (18.60\%), sedangkan kadar lemak tertinggi dihasilkan dari perlakuan A1 (23.89\%). Menurut Amanda (2010), kadar lemak pada suatu produk olahan susu bervariasi tergantung dari penggunaan jenis susu dan metode pembuatan. Berdasarkan berat kering, secara berturut-turut kadar lemak susu fermentasi kering dengan hasil terendah ke yang paling tinggi yaitu A4 (18.60\%), A3 (19.16\%), A2 (22.40\%), dan A1 (23.89\%).

\section{Kadar protein}

Setelah uji sidik ragam dilakukan, diketahui bahwa perlakuan tidak berpengaruh nyata $(P>0.05)$ terhadap kadar protein produk susu fermentasi kering. Berdasarkan persentase berat kering, perlakuan A2 menghasilkan kadar protein produk susu fermentasi kering tertinggi yaitu sebesar $36.66 \%$, sedangkan perlakuan A3 menghasilkan kadar protein terendah yaitu sebesar $34.19 \%$. Tingginya kadar protein pada perlakuan A2 menandakan bahwa saat terjadi koagulasi, kasein yang terhidrolisis lebih banyak dibandingkan dengan yang lainnya (Holland et al. 1989). Kadar protein dari yang tertinggi ke yang terendah berturut-turut yaitu A2 (36.66\%), A1 (35.58\%), A4 (35.09\%), dan A3 (34.19\%).

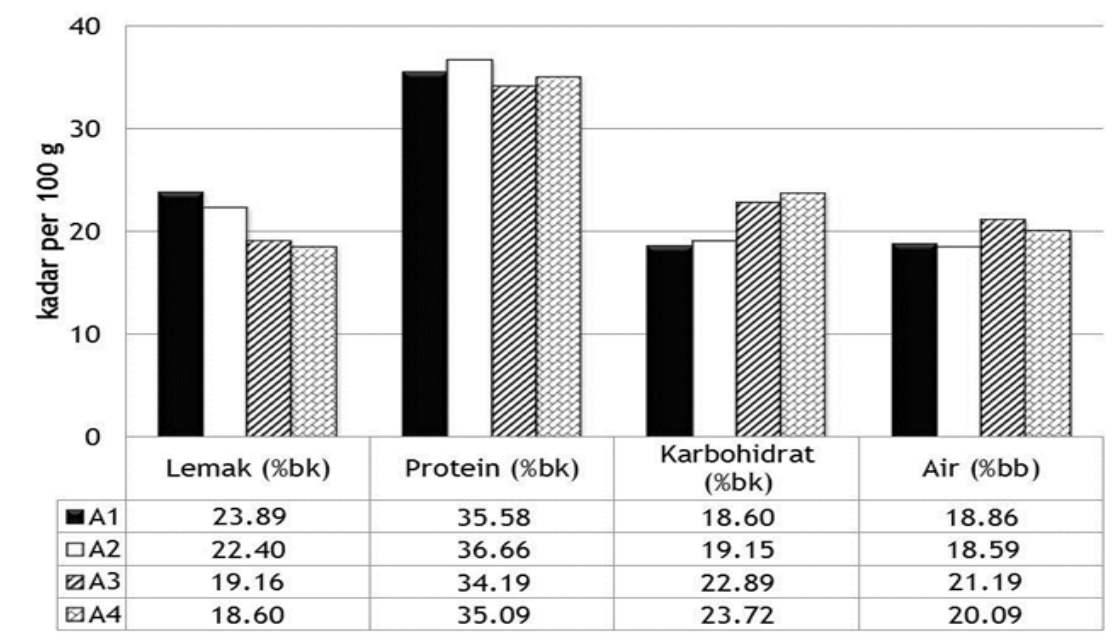

Gambar 2. Kandungan Zat Gizi (Karbohidrat, Lemak, Protein) dan Kadar Air Susu Fermentasi Kering per 100g 


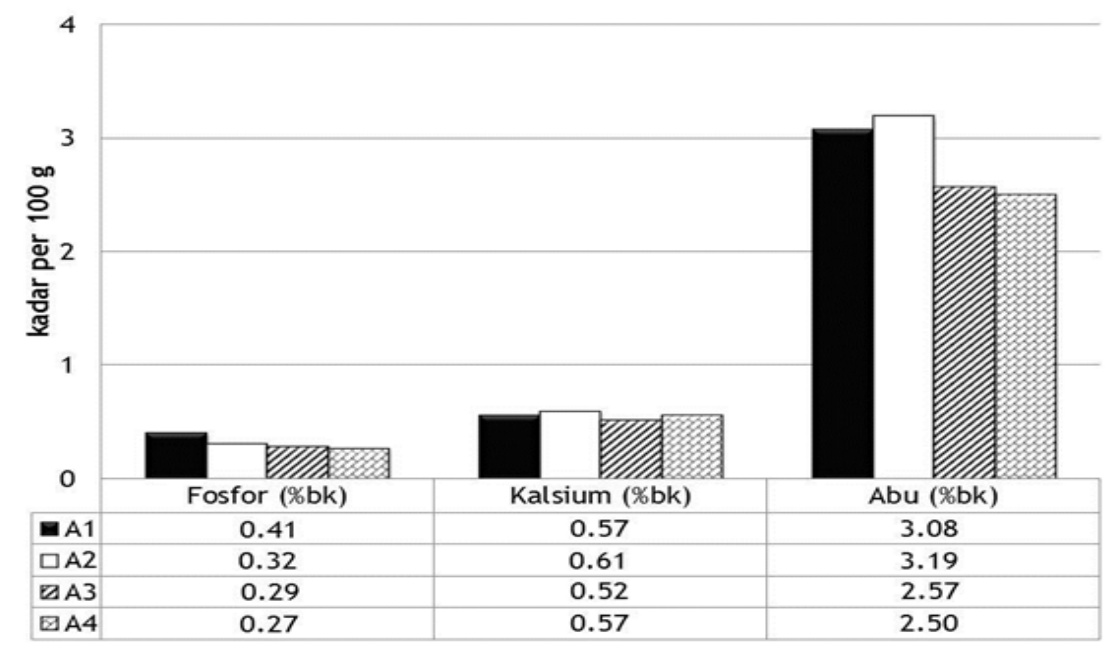

Gambar 3. Kandungan Zat Gizi (Fosfor, Kalsium) dan Kadar Abu Susu Fermentasi Kering per 100g

\section{Kadar karbohidrat}

Uji sidik ragam memperlihatkan bahwa perlakuan tidak berpengaruh nyata $(P>0.05)$ pada kadar karbohidrat produk susu fermentasi kering. Berdasarkan berat kering, kadar karbohidrat dari yang tertinggi hingga yang terendah pada produk susu fermentasi kering yaitu A4 (23.72\%), A3 (22.89\%), A2 (19.15\%), dan A1 (18.60\%). Hal ini berarti perlakuan A4 mempunyai kadar karbohidrat tertinggi dengan kadar sebesar $23.72 \%$ sedangkan perlakuan A1 mempunyai kadar karbohidrat terendah sebesar $18.60 \%$. Menurut Jandal (1995), tingginya kadar karbohidrat terutama laktosa disebabkan oleh perubahan parsial dari laktosa menjadi asam laktat dan komponenkomponen volatil pembentuk rasa selama proses fermentasi.

\section{Kadar fosfor}

Hasil uji sidik ragam menunjukkan bahwa perlakuan berpengaruh nyata $(\mathrm{P}<0.05)$ terhadap kadar fosfor produk susu fermentasi kering. Berdasarkan berat kering, kadar fosfor produk susu fermentasi kering dari yang tertinggi hingga yang terendah yaitu A1 (412.82 mg/100g), A2 (322.25 mg/100g), A3 (293.82 mg/100g), dan A4 (274.57 mg/100g).

\section{Kadar kalsium}

Hasil uji sidik ragam menunjukkan bahwa perlakuan tidak berpengaruh nyata $(P>0.05)$ terhadap kadar kaslium produk susu fermentasi kering. Berdasarkan berat kering, kadar kalsium produk susu fermentasi kering dari yang tertinggi ke yang terendah yaitu perlakuan A2 $(605.20 \mathrm{mg} / 100 \mathrm{~g}), \mathrm{A} 4$ $(569.71 \mathrm{mg} / 100 \mathrm{~g}), \mathrm{A} 1(566.26 \mathrm{mg} / 100 \mathrm{~g})$, dan A3 (523.50 mg/100g).

\section{Kadar air}

Hasil uji sidik ragam menunjukkan bahwa perlakuan tidak berpengaruh nyata $(P>0.05)$ terhadap kadar air produk susu fermentasi kering. Produk terbaik adalah dengan kadar air terendah agar produk dapat disimpan dalam waktu yang relatif lebih lama. Tingginya kadar air pada produk pangan dapat menyebabkan kerusakan yang disebabkan oleh pertumbuhan bakteri patogen, jamur, dan mikroba lainnya (Christian 1980). Kadar air tertinggi sampai terendah, yaitu perlakuan $\mathrm{A} 3$ sebesar $21.19 \%$ (\%b/b), A4 20.09\% (\%b/b), A1 18.86\% (\%b/b), dan A2 $18.59 \%(\% \mathrm{~b} / \mathrm{b})$.

\section{Kadar Abu}

Uji statistik menunjukkan bahwa perlakuan tidak berpengaruh nyata $(P>0.05)$ terhadap kadar abu produk susu fermentasi kering. Berdasarkan Winarno (2008), semakin tingginya kadar abu suatu bahan makanan maka mengindikasikan bahwa kadar mineral suatu bahan semakin tinggi. Kadar abu juga menggambarkan banyaknya mineral yang tidak terbakar menjadi zat yang tidak dapat menguap. Perlakuan A2 memiki kadar abu tertinggi yaitu sebesar (3.19\%) lalu diikuti dengan A1 (3.080\%), A3 (2.57\%), dan A4 (2.50\%).

\section{Analisis Mikrobiologi}

Analisis mikrobiologi diperlukan untuk melihat jumlah BAL yang terdapat dalam produk. Analisis yang dilakukan meliputi uji Total Plate Count (TPC), selektif S. lactis, selektif enumerasi dan selektif differensial.

Produk A1 memakai BAL Streptococcus lactis sehingga uji mikrobiologi yang dilakukan adalah selektif S. lactis dan TPC. Berdasarkan hasil analisis mikrobiologi yang dilakukan, diketahui bahwa ratarata jumlah total bakteri yang terdapat pada produk susu fermentasi kering perlakuan A1 sebesar 10,10 unit $\log \mathrm{cfu} / \mathrm{ml}$ dan rata-rata jumlah $\mathrm{S}$. lactis sebesar 10.07 unit log cfu/ml. 
Produk A2 menggunakan BAL S. lactis dan $L$. casei. Oleh karena itu uji mikrobiologi yang dilakukan antara lain uji TPC, selektif S. lactis, selektif enumerasi dan differensial $L$. Casei. Rata-rata jumlah total bakteri pada produk A2 yaitu sebesar 10.23 unit log $\mathrm{cfu} / \mathrm{ml}$ dan S.lactis sebesar 10,06 unit log $\mathrm{cfu} / \mathrm{ml}$. Selain itu nilai rata-rata uji selektif differensial terhadap L.casei yaitu sebesar 7.52 unit log $\mathrm{cfu} / \mathrm{ml}$ dan uji selektif enumerasi sebesar 7.34 unit $\log \mathrm{cfu} / \mathrm{ml}$.

Produk A3 yaitu produk dengan menggunakan BAL S. lactis dan kultur yogurt (S. thermophilus dan L. bulgaricus). Uji mikrobiologi berupa TPC, selektif S. lactis, selektif enumerasi L. bulgaricus dan S. thermophillus. Hasil pembacaan diketahui rata-rata jumlah total bakteri yang terdapat pada produk A3 yaitu sebesar 8.94 unit log cfu/ml, S. lactis sebesar 8.44 unit $\log \mathrm{cfu} / \mathrm{ml}$, S. thermophilus sebesar 6.83 unit $\log \mathrm{cfu} / \mathrm{ml}$, dan L. bulgaricus sebesar 7.30 unit $\log \mathrm{cfu} / \mathrm{ml}$.

Produk A4 merupakan produk dengan menggunakan BAL S. lactis dan Bifidobacterium longum. Uji mikrobiologi yang dilakukan yaitu TPC, selektif S. lactis, selektif enumerasi dan differensial $B$. longum. Rata-rata jumlah total bakteri pada produk A4 sebesar 9.06 unit log $\mathrm{cfu} / \mathrm{ml}$ dan S. lactis sebesar 8.87 unit log cfu/ml. Hasil rata-rata uji selektif differensial $B$. longum sebesar 7.33 unit log $\mathrm{cfu} / \mathrm{ml}$ dan selektif enumerasi sebesar 7.42 unit $\log \mathrm{cfu} / \mathrm{ml}$.

Berdasarkan standar Codex: 243 (2003), jumlah minimum mikroba hidup yang diinginkan untuk label spesifik produk susu fermentasi yaitu sebanyak $106 \mathrm{cfu} / \mathrm{ml}$ atau sebesar 6 unit log cfu/ml. Karna et al. (2007) dalam laporan penelitiannya menjelaskan bahwa jumlah minimum bakteri asam laktat dari produk susu fermentasi yang layak dikonsumsi dan memberikan manfaat kesehatan adalah seba- nyak 105 sampai 106 cfu/g. Menurut Tannock (1999), jumlah mikroba hidup yang harus terdapat pada produk probiotik adalah sebesar 106-108 cfu/gram. Berdasarkan ketentuan dan standar yang ada, maka semua produk susu fermentasi kering yang diformulasikan dalam penelitian ini sudah memenuhi syarat sebagai produk susu fermentasi yang berpotensi meningkatkan kesehatan.

\section{Uji Mutu Hedonik} Gambar 4.

Hasil uji mutu hedonik dapat dilihat pada

\section{Warna}

Hasil organoleptik panelis menunjukkan mutu warna antara "putih" sampai "cokelat" dengan skor penilaian 2.30-2.60. Hasil uji sidik ragam menunjukkan tidak adanya pengaruh yang nyata $(P>0.05)$ dari perlakuan penggunaan BAL terhadap atribut warna. Produk pada semua formula mempunyai penilaian yang sama yaitu warna putih kekuningan. Hal ini dikarenakan bahan baku yang digunakan pada semua perlakuan adalah susu sapi. Lama proses fermentasi dan pengeringan produk yang relatif sama pada semua perlakuan juga menyebabkan warna produk pada semua perlakuan tidak berbeda nyata.

\section{Tekstur}

Hasil organoleptik panelis menunjukkan mutu tekstur dari produk dengan skor penilaian antara 2.67-3.37. Analisis sidik ragam menunjukkan adanya pengaruh yang nyata $(\mathrm{p}<0.05)$ perlakuan terhadap atribut tekstur. Analisis uji lanjut Duncan menunjukkan bahwa produk $A 2$ beda signifikan dengan produk A1, A3, dan A4. Produk A2 memiliki penilaian tekstur halus sedangkan produk A1, A3, dan A4 memiliki penilaian tekstur sedang sedangkan. Penambahan gula pasir yang dihaluskan kepada curd mempunyai

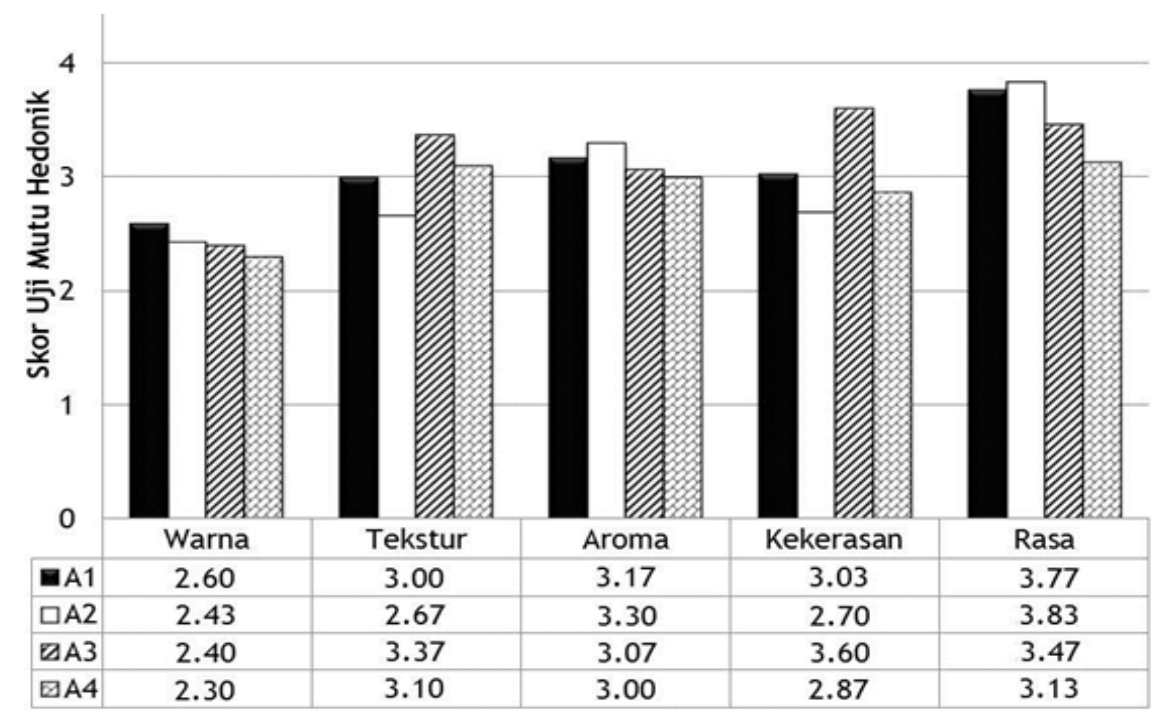

Gambar 4. Skor Rata-rata Uji Mutu Hedonik Panelis terhadap Atribut Warna, Tekstur, Aroma, dan Rasa Susu Fermentasi Kering 
dampak terhadap tekstur produk yang dihasilkan (Manley 2008).

\section{Aroma}

Analisis sidik ragam menunjukkan tidak adanya pengaruh yang nyata $(p>0.05)$ terhadap atribut aroma. Penilaian aroma panelis berkisar antara 3.00-3.17 antara aroma "sangat khas susu murni" sampai sangat "khas susu asam". Seluruh formula mempunyai penilaian yang sama yaitu aroma sedang (antara khas susu asam dan khas susu murni). Pembentukan aroma pada produk fermentasi susu disebabkan oleh beberapa komponen yang dihasilkan pada saat fermentasi seperti diasetil, asetoin, dan butadienol. Komponen paling utama yang berperan adalah diasetil (Quintans et al. 2000).

\section{Kekerasan}

Analisis sidik ragam menunjukkan adanya pengaruh yang nyata $(\mathrm{p}<0.05)$ terhadap atribut kekerasan. Analisis uji Duncan menunjukkan bahwa produk A1 memiliki penilaian kekerasan lembek dan begitu pula pada produk A2 dan A4, sedangkan produk A3 memiliki penilaian sedang. Penilaian panelis berkisar antara 2.70-3.60.

\section{Rasa}

Analisis sidik ragam menunjukkan adanya pengaruh yang nyata $(p<0.05)$ terhadap atribut rasa. Analisis uji lanjut Duncan yang menunjukkan bahwa produk A1 dan A2 memiliki rasa dominan asam, sedangkan A3 dan A4 memiliki penilaian rasa sedang (asam dan manis sebanding). Penilaian produk berkisar antara 3.13-3.83.

\section{Uji Hedonik}

Hasil uji hedonik disajikan pada Gambar 5.

\section{Warna}

Berdasarkan uji kesukaan yang dilakukan, penilaian panelis terhadap atribut warna yaitu antara
3.53-3.87. Nilai tertinggi pada warna yaitu pada produk A4 sebesar 3.87. Berdasarkan sidik ragam yang dilakukan, dapat diketahui bahwa tingkat kesukaan terhadap warna tidak berpengaruh nyata antara satu sama lain ( $p>0.05)$. Hasil menunjukkan bahwa panelis menyukai atribut warna pada keseluruhan formula produk susu fermentasi kering. Hal ini dikarenakan warna produk yang tidak terlalu gelap sehingga para panelis menyukainya.

\section{Tekstur}

Berdasarkan uji kesukaan yang dilakukan, penilaian panelis terhadap atribut tekstur yaitu antara 2.83-3.47. Produk A2 mendapatkan rata-rata nilai tertinggi pada tekstur sebesar 3.47. Analisis sidik ragam menunjukkan bahwa perlakuan berpengaruh nyata terhadap tingkat kesukaan tekstur $(p<0.05)$. Hasil uji lanjut Duncan menunjukkan bahwa penerimaan tekstur produk A1 yaitu biasa dan sama seperti pada produk A2 dan A4, sedangkan A3 tidak suka.

\section{Aroma}

Penilaian uji kesukaan terhadap atribut aroma berkisar antara 3.20-3.53. Penilaian tertinggi pada aroma yaitu pada produk A4 sebesar 3.53. Sebagian besar panelis menilai bahwa keseluruhan produk pada semua formula mempunyai aroma biasa. Hal ini diperkuat dengan uji sidik ragam pada penilaian tingkat kesukaan produk susu fermentasi kering terhadap aroma tidak berpengaruh nyata ( $p>0.05)$.

\section{Rasa}

Penilaian uji kesukaan terhadap atribut rasa berkisar antara 2.97-3.43. Penilaian tertinggi pada atribut rasa yaitu produk A4 sebesar 3.43 yang tidak terlalu asam. Berdasarkan uji sidik ragam yang dilakukan pada penilaian tingkat kesukaan, dapat diketahui bahwa tingkat kesukaan terhadap rasa produk susu fermentasi kering tidak bepengaruh nyata $(p>0.05)$. Seluruh formula mempunyai penilaian biasa.

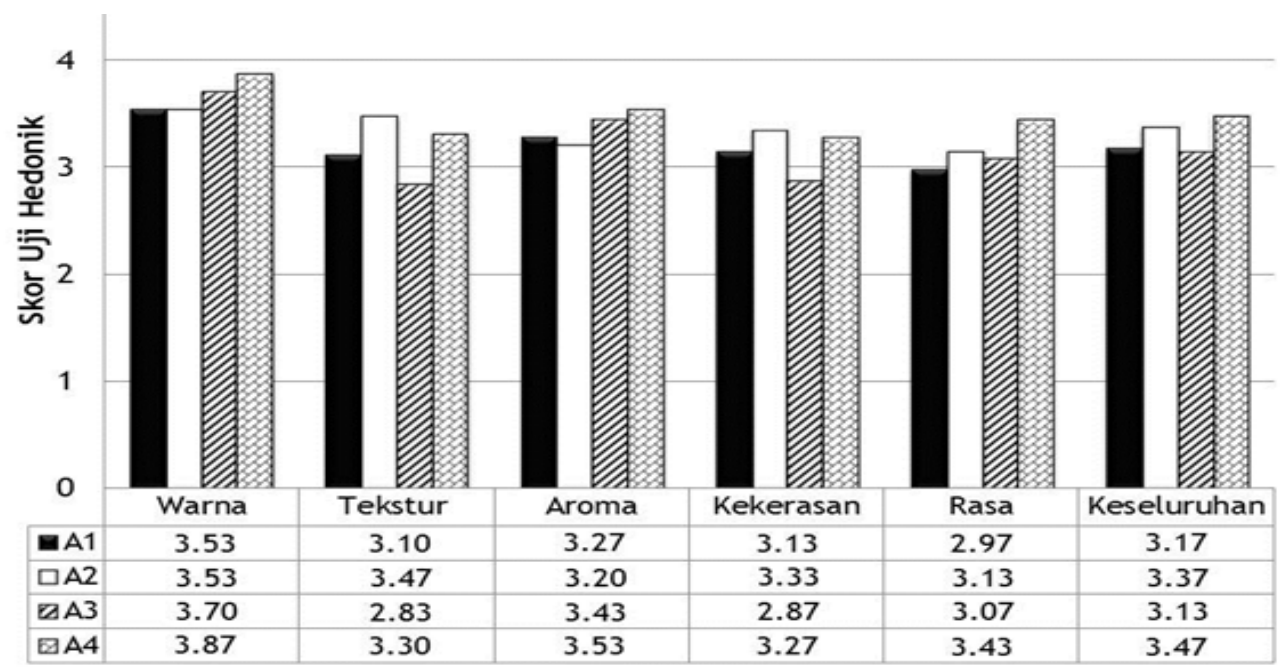

Gambar 5. Skor Rata-rata Uji Hedonik Panelis terhadap Atribut Warna, Tekstur, Aroma, Rasa, dan Keseluruhan Susu Fermentasi Kering 


\section{Kekerasan}

Berdasarkan penilaian terhadap atribut kekerasan, penilaian berkisar antara 2.87-3.33. Penilaian tertinggi yaitu pada produk A2 sebesar 3.33. Berdasarkan sidik ragam yang dilakukan pada penilaian tingkat kesukaan, dapat diketahui bahwa tingkat kesukaan terhadap kekerasan produk susu fermentasi kering tidak berpengaruh nyata $(p>0.05)$. Penilaian terhadap seluruh formula adalah biasa.

\section{Keseluruhan}

Berdasarkan penilaian terhadap keseluruhan produk, rata-rata penilaian yaitu antara 3.13-3.47. Penilaian tertinggi yaitu pada produk A4 sebesar 3.47. Berdasarkan sidik ragam yang dilakukan, dapat diketahui bahwa tingkat kesukaan terhadap keseluruhan produk tidak berpengaruh nyata $(p>0.05)$. Penilian panelis terhadap seluruh formula yaitu biasa.

\section{KESIMPULAN}

Waktu pencampuran susu dengan kultur berdasarkan kurva pertumbuhan adalah Streptococcus lactis, Lactobacillus casei, dan Lactobacillus bulgaricus setelah berumur 4 jam, Streptococcus thermophilus berumur 2 jam, dan Bifidobacterium longum berumur 3 jam.

Produk A4 dengan perlakuan kombinasi starter bakteri Streptococcus lactis dan Bifidobacterium longum terpilih dengan tingkat kekerasan, kelembutan, $\mathrm{pH}$, kadar protein, kadar kalsium yang baik, jumlah Bifidobacterium longum sebesar $2.6 \times 107$ $\mathrm{cfu} / \mathrm{ml}$ sesuai standar probiotik yang ditentukan menurut Codex Standard: 243 (2003). Produk A4 ini memiliki karakteristik warna putih kekuningan, tekstur sedang, aroma antara khas susu asam dan khas murni, kekerasan lunak, dan memiliki rasa asam dan manis yang berimbang yang disukai oleh panelis.

\section{UCAPAN TERIMA KASIH}

Terima kasih disampaikan pada Balai Besar Penelitian dan Pengembangan (BALITBANG) Pasca Panen Cimanggu, Bogor yang telah memberikan sarana dan prasarana penelitian, serta seluruh teknisi dan laboran yang telah memberikan bimbingan.

\section{DAFTAR PUSTAKA}

Apriyantono AD, Fardiaz D, Sedarnawati L, \& Budiyanto S. 1989. Analisis Pangan. Pusat Antar Universitas Pangan dan Gizi, IPB, Bogor.

Caplice E \& Fitzgeralda GF. 1999. Food fermentations: role of microorganisms in food production and preservation. International Journal of Food Microbiology, 50, 131-149.

Codex Standard For Fermented Milks: 243. 2003. Food Agricultural Organization.

Galland L. 2005. Applied Nutrition Inc dalam Encyclopedia of Human Nutrition. Second edition. Elsevier Academic Press, New York, USA.

Hidayatulloh MA. 2011. Analisis Kalsium dan Fosfor pada Susu Fermentasi Kering [tugas akhir]. Program Keahlian Kimia, Program Diploma, IPB, Bogor.

Holland B, Unwin LD, \& Buss DH. 1989. Milk Products and eggs: The Fourth Suplement to Mc Cance and Widdowson's The Composition of Foods, 4 th Edition. Royal Society of Chemistry/Ministry of Agriculture. Fisheries and Food, Cambridge, UK.

Jandal JM. 1996. Studies on dried fermented dairy products prepared from sheep milk. Small Ruminant Research, 21, 217-220.

Karna BKL, Emata OC, \& Barraquio VL. 2007. Lactic Acid and Probiotic Bacteria from Fermented and Probiotic Dairy Products. Philipphines Science Diliman, 19(2), 23-34

Manley D. 2008. Biscuit Doughs: Types, Mixing, Conditioning, Handling. Woodhead Publishing Limited, Cambridge, England.

Rahman A, Fardiaz D, Rahayu WP, Suliantari, \& Nurwitri CC. 1992. Teknologi Fermentasi Susu. Departemen Pendidikan dan Kebudayaan Direktorat Jenderal Pendidikan Tinggi Pusat Antar Universitas Pangan dan Gizi, IPB, Bogor.

Standar Nasional Indonesia. 1992. SNI: 01-2973-1992 Mutu dan Cara Uji Biskuit. Dewan Standar Nasional Indonesia, Jakarta.

Suprihanto AJ. 2009. Pengaruh jenis bakteri asam laktat terhadap kualitas dadih sapi probiotik selama penyimpanan dalam suhu ruang dan suhu rendah. [skripsi]. Departemen Teknologi Industri Pertanian, Fateta, IPB, Bogor.

Tabasco R, Paarup T, Janer C, Pela'ez C, dan Requena T. 2007. Selective enumeration and identification of mixed cultures of Streptococcus thermophilus, Lactobacillus delbrueckii subsp. bulgaricus, L. acidophilus, L. paracasei subsp. paracasei and Bifidobacterium lactis in fermented milk. International Dairy Journal, 17, 1107-1114.

Tannock GW (eds). 1999. Probiotic: A Critical Review. Horizon Scientific Press, England.

Wahyudi A \& Samsundari. 2008. Bugar dengan Susu Fermentasi. Universitas Muhamadiah Malang Press, Malang.

Winarno FG, W Ahnan \& W Widjajanto. 2003. Flora Usus dan Yoghurt. M-Brio Press, Bogor. 